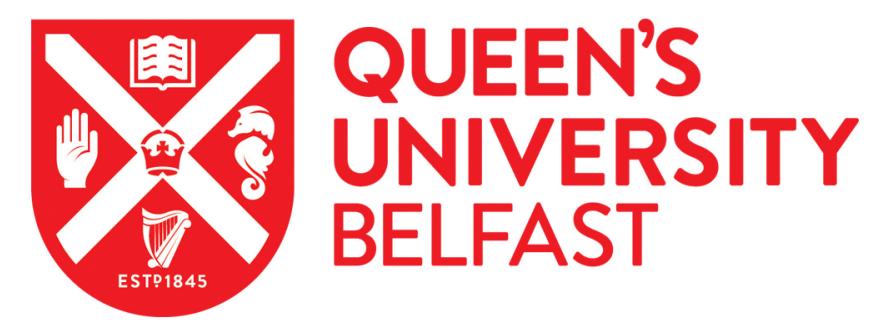

\title{
Participatory Action Research with and within community activist groups: capturing the collective experience of Ireland's Community and Voluntary Pillar
}

Carney, G., Dundon, T., \& Ni Leime, A. (2012). Participatory Action Research with and within community activist groups: capturing the collective experience of Ireland's Community and Voluntary Pillar. Action Research, 10(3), 313-330. https://doi.org/10.1177/1476750312451279

Published in:

Action Research

Document Version:

Peer reviewed version

Queen's University Belfast - Research Portal:

Link to publication record in Queen's University Belfast Research Portal

Publisher rights

(c) 2012, The Authors

\section{General rights}

Copyright for the publications made accessible via the Queen's University Belfast Research Portal is retained by the author(s) and / or other copyright owners and it is a condition of accessing these publications that users recognise and abide by the legal requirements associated with these rights.

Take down policy

The Research Portal is Queen's institutional repository that provides access to Queen's research output. Every effort has been made to ensure that content in the Research Portal does not infringe any person's rights, or applicable UK laws. If you discover content in the

Research Portal that you believe breaches copyright or violates any law, please contact openaccess@qub.ac.uk. 


\title{
Participatory action research with and within community activist groups: capturing the collective experience of Ireland's Community and Voluntary Pillar in social partnership
}

\section{Carney, G., Dundon, T. and Ni Leime, A. Irish Centre for Social Gerontology, NUI Galway, Ireland.}

\begin{abstract}
The inclusion of community activists in policy planning is increasingly recognised at the highest international level. This article shows how the use of Participatory Action Research (PAR) can present a deeper and more holistic picture of the experiences of Civil Society Organisations (CSO's) in shaping national-level social policy. By utilising action-based research, the Community and Voluntary Pillar (CVP) of Ireland's system of social partnership is shown to be an important agent in deliberating national bargaining outcomes (known as the Towards 2016 national agreement). The key contribution of this research is the reflective methodological considerations in terms of PAR design, execution and participant integration in the research process as a way to enrich and develop a deeper and more informed community of practice.
\end{abstract}

\section{Keywords}

Participatory action research, Ireland, Community and Voluntary Pillar 


\section{Introduction}

The notion that there is a role for civil society organisations in formulating public policy has been recognised at the highest international level (United Nations, 2008). Action research methodologies allow for the analysis of deliberative democratic processes with and within Civil Society Organisations (CSOs). In Ireland, community engagement in social and economic development has been the subject of academic and activist debate since the Irish government added a Community and Voluntary Pillar (CVP) to the system of social partnership in 1998 (Dundon, Curran, Maloney \& Ryan, 2006). The CVP is a mechanism which provides for a degree of regulated access to government decisionmakers for those organisations that represent citizens who may be subject to labour market volatility, political or social exclusion. Social partnership itself is a process of consensus policy-making whereby government agree pay levels and social and economic policy with four key 'pillars': employers' organisations; trade unions; farmers groups; and community and voluntary organisations (Teague \& Donaghey, 2009).

This research presented in this paper uses Participatory Action Research (PAR) (Chambers 1997; Kemmis \& McTaggart, 2000) to capture the experiences of Civil Society Organisations who, collectively, constitute the CVP. These CSO's actively campaigned for and bargained with government and other policy-makers, leading to a negotiated 'lifecycle framework' as part of the national partnership agreement, Towards 
2016. The lifecycle approach is an approach to institutional design and policy delivery affecting a number of "at risk" groups. The approach works on the assumption that risk of social exclusion differs according to a person's life stage. Children or older people can be identified as having distinct needs according to their life stage. People with disabilities are recognised as facing lifelong difficulties across lifecycle stages. While CSOs and the CVP appear to have secured a new social policy framework within Ireland's national corporatist regime, it has also been argued that the community sector has been compromised in favour of economic stability and the promotion of a neoliberal political agenda (Meade, 2005). Thus the issues surrounding social partnership and the lifecycle framework remain contentious. Absent from this debate has been a robust empirical study which captures the processes and dynamics of CSO engagement in such government-led decision-making apparatus, especially from the perspective of community activists and CSO members.

This article reviews how PAR was employed to paint a holistic picture of the lived experiences of CSOs in the CVP of social partnership. The use of PAR created a trusting research environment. Ultimately, the PAR process contributed to a new understanding of the CVP, challenging existing literature on the experience of these CSO's in social partnership. Previous literature took a critical approach, presenting the CVP as a willing victim in a state- led programme to civilise civil society in Ireland 
(Meade, 2005; Murphy, 2002). Taking a PAR approach allowed us to include more forms of evidence, more participants, and ultimately to produce a more complete and practical interpretation of the role of the CVP in Ireland's system of decision-making. These insights, offered as reflections in this paper, lead to a further key contribution - in demonstrating how PAR is a useful mode of inquiry where disagreement about what is 'truth' and 'interpretation' (Heshusius, 1994: 15) has depleted trust amongst participants. In order to achieve this, the article continually refers to the usefulness of various aspects of PAR throughout our analysis of the case. We are open and transparent about both positive and negative aspects of the PAR journey which are used to enrich a conversation about one aspect of the action research agenda. Our PAR study can be viewed as the next step in building a more holistic interpretation of the experience of CSO engagement with the state in Ireland. In advancing this contribution the article is structured as follows. First, a contextual background to the research project and Ireland's social partnership model is explained, including the specific role for CSOs within its CVP. Next, the importance of an action-research agenda is reviewed; in particular the specific role of the PAR methodology. Two main sections form the bulk of the reflective analysis and contribution. The first develops a reflective contextualisation of PAR in terms of recruiting active and willing participant organisations, building trust and empathy, and considering the utility of the research techniques and analytical tools deployed. The next section integrates the reflective 
views of the participants themselves, noting some important and practical limitations. Finally, the conclusion summarises the main contribution of the paper and describes how it adds to an on-going conversation in relation to PAR methodologies.

\section{Context and background to the research}

The larger study assessed the impact of the life cycle approach on policy-making for CSOs participating in the CVP of social partnership. The broad aims for the larger research project included: to engage CSOs as collaborators in the project; to understand the processes of decision-making within the CVP of social partnership; to explain the diffusion of power relations between CSO members and State agencies, both inside and outside the social partnership framework; and to disseminate the research findings to policy-makers, non-governmental organisations (NGOs) and academics at a national and international level.

A brief contextual background to Ireland and the substantive policy role of CSOs within the social partnership arrangement is now presented. Ireland faced a unique and unprecedented set of circumstances in the 2008 to 2011 period when the research project took place. This period was one of huge change for the Irish economy as a whole. Prior to the global economic recession, Ireland was recognised as an economic miracle, a success story of the expansion of global capitalism via the post-war political 
project for European economic cooperation (Murphy, 2000). Social partnership was credited with this success. As GDP rose, the community sector began to argue against rising inequality. The lifecycle was introduced as part of the Developmental Welfare State, a blueprint for social development negotiated by all the social partners, and led by the CVP (National Economic and Social Council, 2005). By 2008, Ireland had gone from having the highest rate of economic growth and prosperity for more than a decade in Europe, to suddenly requiring the direct assistance of the European Central Bank (ECB) and International Monetary Fund (IMF). Within the global financial crisis Ireland was particularly exposed to the vagaries of international capitalism, largely because of its over-reliance on cheap global finance to fuel a property boom along with minimal regulations to curb the activities of banks and other multi-national organisations (McDonough \& Dundon, 2010). The basis of what became known as the 'Celtic Tiger' rested on several factors: easy access to cheap global finance, low corporation tax to attract foreign-direct investment, support from trade unions, and cooperative institutions such as social partnership to legitimise wage rates, welfare state reform and decision-making. A founding pillar of economic growth was the concept of cooperation and engagement with a range of social partners. To this end Ireland's tripartite model of bargaining was re-branded as social partnership; this was first introduced in 1987 and ran consecutively for over 20 years with seven negotiated agreements and was premised on voluntary dialogue between the State and multiple 
stakeholders (Wilkinson, Dundon, Marchington \& Ackers, 2004; Dundon et al., 2006). The latest agreement, Towards 2016, was negotiated in 2006 and included the lifecycle approach with the incorporation of CSO members through the CVP. Importantly, cooperative engagement was premised on inclusion in decision-making that set wages, taxation, welfare and social policy change (Teague \& Donaghey, 2009). According to Murphy (2002), social partnership was 'the only game in town' in terms of policy planning at the time.

All changed amidst recession and financial crisis. Social partnership in Ireland has become associated with an unhealthily close relationship between unions, employers and the government. Faced with extensive austerity measures and the potential loss of sovereignty with ECB and IMF bail-outs, the government officially walked away from social partnership in 2010 when they decided to impose cuts rather than negotiate reform through the institution of social partnership (Roche, 2010). A new coalition government, elected in early 2011, abandoned social partnership, although elements of the lifecycle approach negotiated in the Towards 2016 agreement remain active in relation to social policy objectives if not specific strategic plans. It is with this background, context and circumstances encountered by the researchers and CSO participants, that we reflect on the PAR method as a tool to advance a deeper and more refined understanding of social policy decision-making in action. 


\section{Contribution of the study to the action research agenda}

The crucial balance to find in all research is that between the 'replication standard' (an approach that is so methodologically honed and explicit that any other researcher at another time addressing the same research question would find the same results), versus deeper, epistemological questions, such as what the study contributes to our knowledge of the social world. PAR is seen to be stronger on reaching an approximation of the truth, at the cost of methodological sophistication: 'there may be a trade-off between methodological sophistication and "truth" in the sense of timely evidence capable of giving participants critical purchase on a real situation in which they find themselves' (Kemmis \& McTaggart 2000, p.591). For this project, action research was chosen as a methodology because of a political and ethical commitment to the participants. As such, the study builds on a body of work pioneered by Lewin (1946), whose work on labourmanagement relations in England was later developed in a Scandinavian context by Emery and Thorsrud (Erikson, 2011: 51). As our study is conducted on a smaller scale, it contributes to the later Frankfurt School tradition of challenging positivist inquiry by looking at 'local and contextualized meanings' (Brydon-Miller, Kral, Maguire, Noffke and Sabhlok, 2011: 390; Gomez and Kuronen, 2011). The significance of context is increasingly recognised in research which aims to provide some basis on which an 
organisation can change or innovate (Naschold, Cole, Gustavsen and van Bieum, 1993, p.161; Erikson, 2011, p. 51).

For this study, it was important to work with all CVP member organisations in order to generate a more holistic picture of the experience of CSO's working within social partnership and especially the new lifecycle policy direction. The project aimed to contribute to what Denzin (2011, p. 644) calls “our collective endeavor" as qualitative methodologists, by demonstrating how action research, clearly and ethically conducted can offer a more complete picture of a complex, on-going policy process. The PAR method deployed meets the three requisite conditions for pragmatic action research identified by Greenwood and Levin (1998, p. 152), namely: i) construction of arenas for dialogue; ii) co-generative research; and iii) the use of multiple methods and data sources. In doing so, the paper makes three substantive and related contributions to the broader action research literature. Firstly, the paper is an example of a detailed and transparent account of how one type of action research, namely, the formative evaluation can be used to investigate an important policy initiative at the national level. Secondly, this account is enriched and emboldened by the inclusion of critical reflections of participants and researchers, identifying problems and opportunities in attempting to use PAR in this way. Thirdly, while the paper offers a useful example of a formative evaluation, the reflections shared demonstrate how PAR can be a useful mode 
of enquiry where trust has been lost. In this case, the well-meaning work of many previous researchers of the CVP led to a combination of distrust of researchers and research fatigue amongst participants.

In line with Kemmis and McTaggart's (2000, p.592) articulation of action research as a setting in motion of 'processes by which participants collectively make critical analyses of the nature of their practices' the transformative research design sought to engage participants in an environment free from governmental scrutiny. The final research report presented to the Minister for Social Protection in May 2011 was the result of a co-generative research process. Neither participants nor researchers could have independently produced such a nuanced understanding of the experience of CSOs engagement within social partnership. The validity of the project's findings and recommendations lay not only in its articulation of the collective experience of CSO engagement in partnership, but also in how it served as an example of how investment in participatory action research can showcase the tacit knowledge and unique expertise of CSOs at time of national crisis. This research seeks to bridge the link between academic theories and what is happening in the real world. The theoretical contribution builds on the action research agenda advanced by Gustavsen et al (1997, p.145) with an explicit concern for 'the issues of democracy/participation in the light of the demands imposed by global competition'. 
In contributing to this agenda the current research project had both a reflective and an action element; what Greenwood and Levin (1998, p. 130) consider as 'formative evaluation', in which there is reflective evaluation while a programme is in active operation. Participant organisations are positioned as the leading experts on the lifecycle approach and negotiated the approach with government through the social partnership process. Our article is then broadly relevant to the major work conducted in Scandinavian corporatist systems and extensively recorded in the work of Gustavsen, Toulmin, Grootings and others (Toulmin \& Gustavsen, 1996; Grootings, Gustavsen \& Hethy, 1991). This connects with what Gouin, Cocq \& McGavin (2011) identify as the important 'collective' role of participatory action research, reported in an NGO feminist environment. Elsewhere, Aziz, Shams \& Khan (2011) argue that female 'empowerment' shaped the outcomes and processes of research around health and women's rights within a Muslim context. Ataöv et al (2010), drawing on migrant worker rights in Norway, refer to related debates concerning inclusion and exclusion status in decision-making. The professionalisation of CSOs in democratic systems of governance are important issues according to Fyfe (2005). In the Irish context, while some progress has been made in problematising the role of civil society in social partnership (Gaynor, 2009), much of the empirical research has been conducted on an ad hoc basis (Daly, 2007; Meade, 2005). The critical approach taken by some authors, 
which has, arguably, made an important contribution to the literature questioning state led incorporation projects, has tended to depend on 'public commentaries,' (Meade, 2005), literature reviews (Daly, 2007) or the opinion of some activists (Murphy, 2002).

Previous research on community engagement has tended to conclude that the formation of the pillar has led to co-optation of CSOs against an emerging neo-liberal agenda (Daly 2007; Larragy 2006; Meade, 2005; O’Donovan, 2002). This criticism is in large part due to the fact that membership of the CVP is by the invitation of government only. It is also worth noting that the seventeen member organisations are not representative of the entire community sector in Ireland. Rather the group of seventeen represents the main sectional interest groups. The decision to take up the government's invitation to participate in social partnership by some CSOs has been attributed to a realisation that when it came to initiating social development 'other methods yielded little success' (Larragy, 2006, p. 393). Our research sought to make an empirical contribution to this literature, by providing a robust and ethically sound research design which captures the complexity of CSO engagement in the institution of social partnership in Ireland. Moving away from dichotomous disagreements about what is truth and what is interpretation, we used PAR to include more participants, gather more diverse forms of evidence, ultimately, presenting a broader representation of CSO engagement with the State. In the context of the current PAR project and the centrality of collective-based 
community organisations, Figure 1 provides a graphical representation of the position of the CVP within social partnership, alongside other social partners.

Figure 1: The Six Pillars of Social Partnership

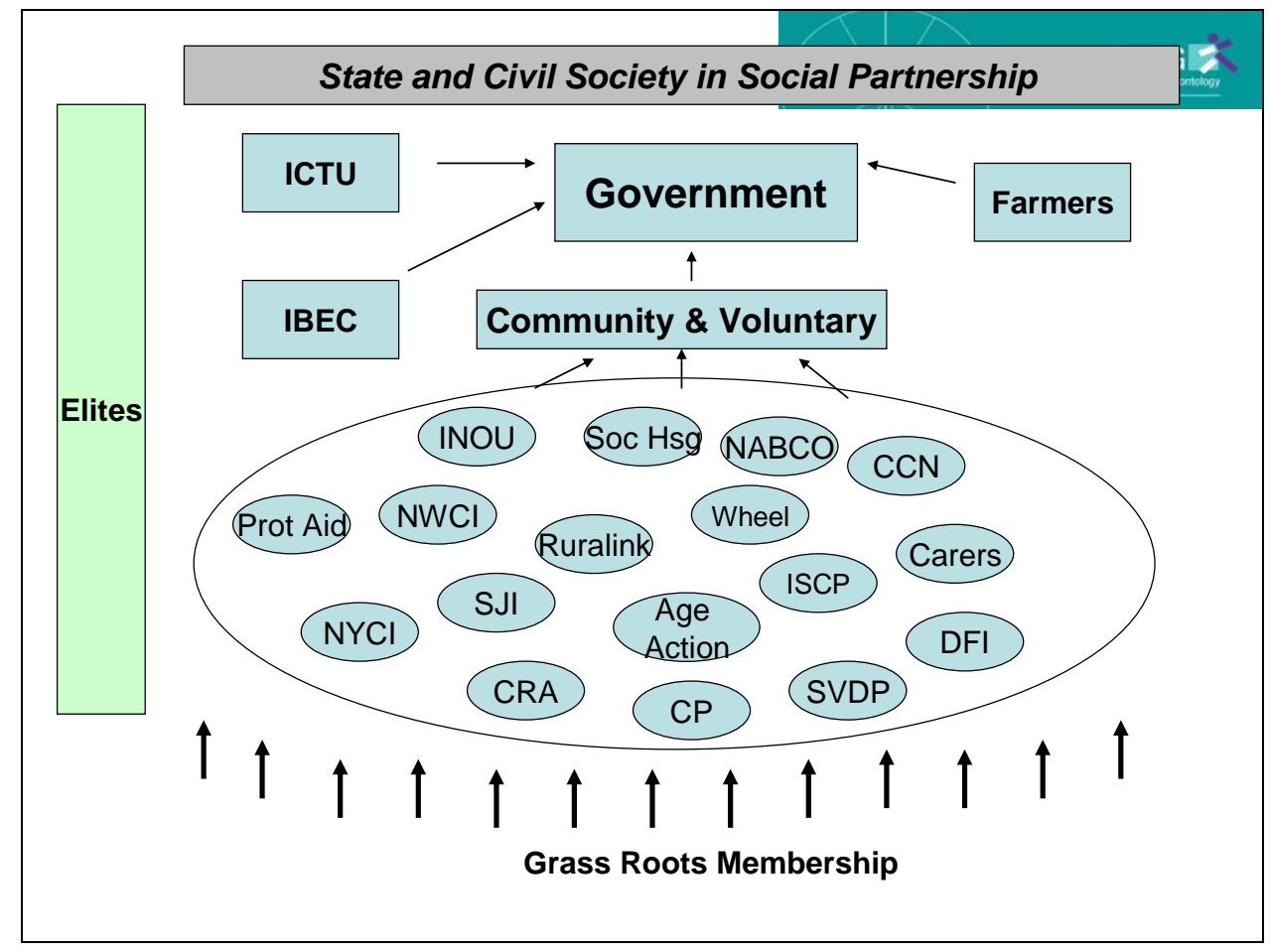

The six pillars of social partnership include the Irish Congress of Trade Unions (ICTU), the government through the Department of the Taoiseach (Prime Minister), Irish Business and Employer's Confederation, a number of farmers' organisations, a conglomerate of environmental organisations (since 2009) and the seventeen CSO 
members that collectively make up the Community and Voluntary Pillar (CVP), and all of whom took part in this research, outlined in full in Table 1

\section{Table 1 Member organisations of the Community and Voluntary Pillar}

\begin{tabular}{|c|c|}
\hline Name of Organisation & Mission \\
\hline Age Action & Advocacy organisation for older people \\
\hline Carers Association & Advocacy organisation for family carers in the home \\
\hline Children's Rights Alliance & Umbrella organisation of children's rights groups \\
\hline Community Platform & $\begin{array}{l}\text { Umbrella organisation facilitating solidarity amongst } \\
\text { organisations in the Community \& Voluntary sector }\end{array}$ \\
\hline $\begin{array}{l}\text { Congress Centres for the } \\
\text { Unemployed }\end{array}$ & Unemployed members of trade unions \\
\hline Disability Federation of Ireland & Advocacy organisation for people with disabilities \\
\hline Irish Council for Social Housing & National Federation representing social housing orgs. \\
\hline $\begin{array}{l}\text { Irish National Organisation of the } \\
\text { Unemployed }\end{array}$ & Advocacy organisation for unemployed people \\
\hline Irish Senior Citizens Parliament & Advocacy organisation of older people \\
\hline Irish Rural Link & Campaigns for sustainable rural communities \\
\hline $\begin{array}{l}\text { National Association of Building } \\
\text { Cooperatives }\end{array}$ & Campaigns for Co-operative housing movement. \\
\hline National Women's Council & Umbrella organisation of women's rights groups \\
\hline $\begin{array}{l}\text { National Youth Council of } \\
\text { Ireland }\end{array}$ & $\begin{array}{l}\text { Representative/umbrella organisation for youth } \\
\text { organisations }\end{array}$ \\
\hline Protestant Aid & Church of Ireland charity \\
\hline $\begin{array}{l}\text { Social Justice Ireland (formerly } \\
\text { CORI Justice) }\end{array}$ & Catholic (and lay) charity and think tank. \\
\hline Society of St. Vincent de Paul & $\begin{array}{l}\text { Catholic anti-poverty charity providing services and } \\
\text { advocacy }\end{array}$ \\
\hline The Wheel & Capacity building of $\mathrm{C} \& \mathrm{~V}$ sector \\
\hline
\end{tabular}




\section{Reflexivity and contextualisation of the PAR approach undertaken}

\section{The research team, funding sources and objectivity}

The overarching research project aims presented earlier were part of a competitive peerreviewed research proposal submitted to and funded by the Irish Research Council for Humanities and Social Sciences (IRCHSS). ${ }^{\text {ii }}$ The proposal demonstrated the potential for the project to address gaps in extant knowledge around social policy inclusion and decision-making processes within social partnership. In terms of methodology, it was also argued in the funding proposal that much academic research had a tendency to view CSOs as passive subjects who had been studied and scrutinised from afar, rather than as active agents capable and able to influence decisions for themselves. Therefore, the research was not initiated by CSO members of the CVP, nor was it commissioned by government directly, but funded as a result of a competitive blind peer review process. In addition to objectivity and academic credentials, the researchers also had a high degree of familiarity with the processes of community-based decision-making and collective bargaining. In particular, the research team was aware that there is no formal funding stream for research and development in the community sector. Importantly, upon securing the funding, the research was presented to members of the CVP as an opportunity for activists and researchers to work together to capture the unique and tacit knowledge of the community sector in improving policy for their constituent groups within the social partnership process. As action researchers the authors made a 
commitment to listen to what participants had to say, to revise methods where appropriate and be inclusive and reflective throughout.

\section{Research participant recruitment}

Once the research proposal gained approval from the IRCHSS, the process of participant engagement and recruitment began. Like many real world research projects, stages and events do not always run as smoothly as often portrayed in textbook descriptions. Indeed, in the initial stages, CSO members were resistant to being 'researched' as a collective pillar. Furthermore, an offer to present the research proposal and subsequent data collection plans to the pillar was declined. The research team was instead asked to contact individual CSO member organisations with individual invitations to participate. Reflections on this and other significant issues are elaborated next.

Each of the 17 member organisations took part in a separate one-to-one interview, typically involving the senior officer or the person designated as the social partnership coordinator for the participant organisation. In using this approach we drew on the work of Palshaugen (1997) and others, in recognising that there is no uniform approach to capturing the diversity of organisations in this strand of action research. It became apparent that previously published research had angered some members of the pillar, 
who saw research as at least troublesome and at worst destructive. All participants could see the utility of the proposed research as long as the topic of the research stayed focused on the 'lifecycle approach.' No incentives to participate were offered. ${ }^{\text {iii }}$ As the formative evaluation progressed, some participants reported that engaging in the research process was useful for reflection on their own work, elaborated later.

Trust and empathy-building in Participatory Action Research

The action-research process itself was highly iterative and the research team had to continuously engage in a trust-building process to ensure that all $17 \mathrm{CSO}$ members felt comfortable participating. As similarly reported by Dundon and Ryan (2010), engagement with politically astute activists was essential to cement researcherparticipant empathy, to move beyond description and into a space where interviewees could feel free to discuss contentious issues. This was especially important given that members felt previous research was less than transparent with the CVP as a collective entity. In order for this research to be valid, and genuinely participatory, time and care had to be taken to ensure that full membership of the pillar took part in the research. This was the first step in truly understanding the pillar as a collective entity. It was at this point that the in-built reflexivity of the PAR method became a key strength as it allowed the team to listen to participants and seek their input in terms of refinement and design. 
Building on the findings of the separate interviews with each CSO member group, it became evident that the CVP was at times regarded as a construct of government by CSO members. It was therefore a mistake to view the CVP as a unified collective component in social partnership. Instead, we needed to reassess the approach and recognise this was now a study of 17 CSOs who may or may not have a collective standpoint on social policy.

The individual interviews were completed by September 2009. Later that year, all participants were invited to attend an information meeting. This meeting proved crucial in recruiting participant organisations. When there were later (inevitable) disagreements about the content of the discussion at deliberations, the trust established through this iterative process of engagement proved vital in two respects. First, it allowed the researchers to retain integrity by sticking closely to the research questions and objectives of the original proposal which participants were by now familiar with and generally supportive toward (Greenwood and Levin, 1998, p. 134). Secondly, the trustbuilding exercise allowed the formative evaluation to stay on track as social partnership stalled as the Irish economic and political landscape became increasingly volatile and unstable (McDonough \& Dundon, 2010). Indeed, the micro politics shaping social partnership as a government-led institution was exposed as a major cause of what some 
described as an elite consensus at the heart of Ireland's severe recession. Although the system of social partnership was criticised, this did not mean the model failed to deliver gains for some other CSO participants who remained advocates of the principles of cooperation and engagement through social partnership. Given that this is real world action research, disagreement and diversity among such activist CSOs is not in itself unusual or surprising. The added value for this paper is that the processes and stages of trust-building through a PAR approach of listening and involvement maintained the equilibrium of the project throughout this period. Ultimately, the trusting environment created by the PAR process contributed to a deeper understanding of the CVP.

\section{The participatory mode of engagement}

The final research design maintained key elements of the original plan to compare how different lobbies used the institution of social partnership to represent vulnerable groups. The participatory process allowed the research team to adjust the design in light of changes to the significance of social partnership as a policy-making institution with the onset of the global recession from 2008. Thus the participatory mode of engagement led to refinement of the research design in tandem with participants. This allowed the research team to capture what they now saw as most relevant to the implementation of the lifecycle approach. A deliberation was to be held for each lifecycle stage (older people, people with disabilities, people of working age and children). Each CSO 
member organisation was free to choose which meeting(s) was relevant to their work, so all CSO members were invited to attend all deliberations. At the request of the many organisations who identified their work as 'cutting across' the lifecycle, two extra deliberations for 'cross-cutting' groups were held. Participation between the different specific lifecycle stages varied enormously. Cross-cutting groups attracted the greatest number of participants. By contrast, two deliberations involved only two CSO members. This was to be expected given that some life cycle stages were represented by only three organisations in the CVP. Some participants took part in a number of deliberations, while others participated in just one. All member organisations of the CVP who could not attend an individual deliberation had been interviewed or had attended an earlier group meeting.

In the final analysis both participants and researchers were confident that the mode of engagement added validity and reliability to the study as opportunities to influence the research design and outcome held constant for participants across multiple lifecycle deliberations. Table 2 summarises the final research design including the mode of engagement and its purpose to the research project and to the participant organisations. 
Table 2. Participatory Modes of Engagement

\begin{tabular}{|l|l|l|}
\hline Method & Mode of Engagement & Purpose \\
\hline $\begin{array}{l}\text { Semi-structured } \\
\text { interviews }\end{array}$ & $\begin{array}{l}\text { Individual interviews } \\
\text { between one member of } \\
\text { research team and one } \\
\text { member of CVP } \\
\text { organisation. }\end{array}$ & $\begin{array}{l}\text { Provide information to } \\
\text { participants on an individual basis } \\
\text { and gather background } \\
\text { information to inform the research } \\
\text { design. }\end{array}$ \\
\hline Information meeting & $\begin{array}{l}\text { Group meeting to which all } \\
\text { members of CVP were } \\
\text { invited. }\end{array}$ & $\begin{array}{l}\text { To provide information on } \\
\text { project, feedback from interviews } \\
\text { and demonstration of research } \\
\text { methods. } \\
\text { Brainstorming, grouping and } \\
\text { ranking in two groups of seven. }\end{array}$ \\
\hline $\begin{array}{l}\text { Individual group } \\
\text { deliberation }\end{array}$ & $\begin{array}{l}\text { Group meeting to which all } \\
\text { members of CVP were } \\
\text { invited. }\end{array}$ & $\begin{array}{l}\text { Brainstorming, grouping and } \\
\text { ranking in groups from 2-6. }\end{array}$ \\
\hline $\begin{array}{l}\text { Final Reflection } \\
\text { Meeting }\end{array}$ & $\begin{array}{l}\text { members of CVP were } \\
\text { invited. }\end{array}$ & $\begin{array}{l}\text { Discussion and reflection on draft } \\
\text { report, including title, } \\
\text { presentation and plans for public } \\
\text { launch of research report. }\end{array}$ \\
\hline
\end{tabular}

Data Collection Techniques and Analytical Tools

A number of different research tools were utilised to record participant interaction and general findings at each of the lifecycle deliberations. These methods are explained in detail here in the interests of offering as transparent an account as possible. A number of techniques favoured by participants included: brainstorming, diagramming, mapping, ranking, and use of matrices. All or some of these methods were used at each deliberation. Participants were invited to engage with the research questions using 
inclusive and equal means. Each participant was provided with a set of post-it notes and asked to list one idea per post-it note, in response to the following questions:

- What are the priority issues for each lifecycle group?

- What strategies are used to address these issues?

- What impact has the lifecycle framework had on participants' organisational strategies used to represent their constituents?

- What potential has the lifecycle approach to enhance or undermine intergenerational relationships?

The participants' responses were subsequently placed on a flipchart by the researcher who then facilitated wider discussion by all groups in attendance. After discussion, participants were invited to group similar ideas and rank them in order of importance. In this way, the relationships between ideas were mapped. Where disagreement existed on ideas, a ranking exercise helped to work out differences. The result is a dataset which includes a list of ideas, group decisions around those ideas, and a final diagram or matrix illustrating the collective responses of each deliberation on a particular issue.

Figure 2 illustrates the evolution of data-gathering techniques from the raw data to analytical tools used by the researchers and the participants at a deliberation meeting. The first photograph (2a) shows all the issues identified as priorities according to the 
CSO members attending the session for the older people's stage, typically through a brainstorming exercise. Then participants were asked to consider headings and thematic clustering of the priority issues identified. In photo $2 \mathrm{~b}$ the thematic headings have been added following agreement by participants (circled to the left of photo $2 \mathrm{~b}$ ) and prioritised issues grouped by thematic cluster according to participants. Finally, in photo $2 \mathrm{c}$, the importance and significance of the clustered issues were prioritised, again by participants themselves.

Figure 2: Data trail using Participatory Action Research

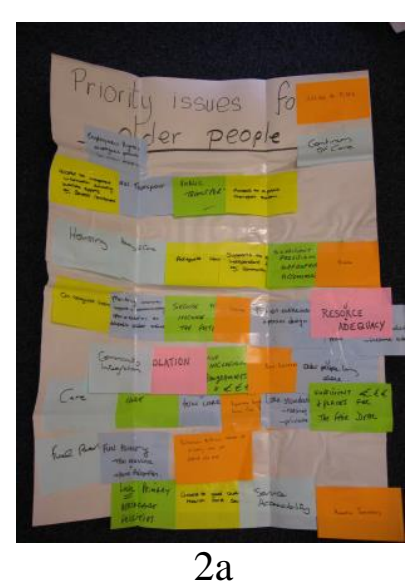

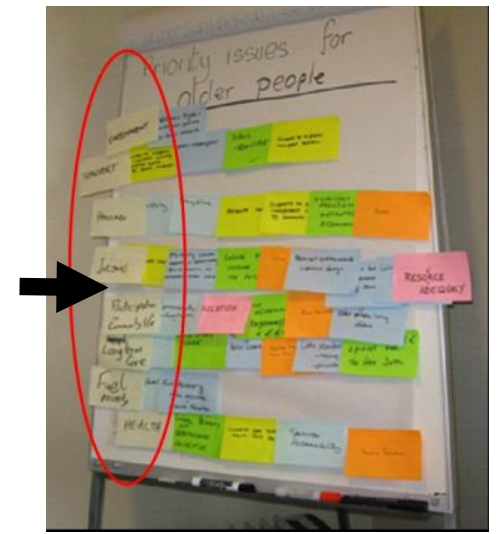

$2 b$

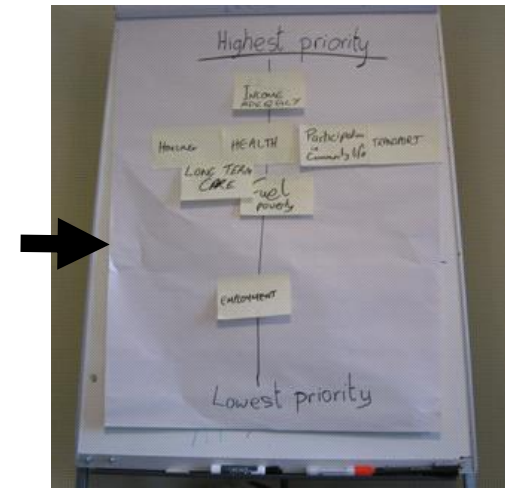

$2 \mathrm{c}$ 
Each deliberation meeting found different issues, strategies and ranking of issues according to participants concerned with each lifecycle stage. In addition to the notes and priorities for each CSO group, handwritten notes were taken at each deliberation by one member of the research team. (Participants had requested that the meetings not be audio-recorded). These notes were subsequently reviewed and verified by a different member of the research team. Summary reports of the research notes were then circulated to participants, who were given two weeks to make comments or offer clarifications. This process occurred in early 2010.

A further level of validation was then added to the analysis by forming a qualitative internal review panel. The research team met to discuss the research findings and consider any subsequent changes or amendments returned from participants. No substantive changes were suggested by participants following their two week review period. At this point, each team member separately reviewed each lifecycle deliberation report to establish, on a question-by-question basis, the most significant insights and findings. For the most part, researchers autonomously identified similar themes as prominent. Where there was full agreement that a particular point was relevant, it was included in the final report. Where there was disagreement, discussion followed until the team reached agreement or further clarification was sought if the issue was unique to a single CSO member. 


\section{Participants' perspective and researchers' reflections on PAR}

Feedback and reflections from participants were sought at the end of each lifecycle deliberation, and again when the project ended at a final results sharing meeting in March 2011. All participants received the final research report prior to its public dissemination (Carney, Dundon, Ni Leime and Loftus, 2011). Those members who were quoted in the report were contacted directly to ensure that they were happy with the context in which their anonymous quote was to be used. All participants were given two weeks to consider the report and include any amendments or suggest changes or corrections. Participant organisations who had engaged enthusiastically with the research process in earlier data gathering stages, again demonstrated their commitment to the process. In all, eight organisations formally responded to the report and actively participated in a final project meeting in March 2011. Participants made valuable contributions, particularly in refining the implications of the reported findings of the research given the changed political and policy environment, as briefly described in Section 2 above.

Several participants stated that they found the sessions to be useful because it gave them the space to discuss the priority lifecycle issues without a watchful government eye so often present within the social partnership system. It also afforded participants an 
opportunity to consider other CSO members' priorities, which facilitated mutual learning. Some participants reported that the research process gave them a chance to tease out issues and they welcomed the opportunity to answer difficult questions. Importantly, using post-it notes gave participants more control over the generation of ideas and gave those who were less vocal the tools to ensure that their point of view was articulated. Moreover, participants commented extensively that the research enabled them to reflect on achievements, air differences between groups, and enable mutual learning that typically did not occur in the CVP itself. In short, by participating in action-led research, CSO members were able to track their own thinking and to realise that there were common themes across other member organisations, concluding that as a collective body, the CVP was much more cohesive than initially imagined by participants themselves.

However, and as might be expected among the type of activist CSOs involved here, some participant groups were critical, and these point to important limitations and lessons for PAR methods. For example some CSO members felt constrained by the research methods used in one of the group deliberations. As the methods were designed to reach consensus, a small number of participants commented that the while disagreements were reported, the full extent of discord during the session was not always clear in the report. A minor concern was that some lifecycle deliberations 
included a small number of participants, which meant that views and involvement was limited to those with a vested interest in that particular lifecycle issue (e.g. age or disability). Participants from one of the cross-cutting deliberations felt that the research focus on the lifecycle approach limited their contribution which was not age related but concerned with broader equality and social justice paradigms, or more focussed on homelessness, issues for migrants or women of all ages. Perhaps one of the more important practical limitations and a lesson to be considered for the future, is that the PAR method was found to be especially labour intensive for CSOs who have to operate with limited resources.

\section{Researcher's Reflections on the Formative Evaluation}

Engaging in a participatory action research during a time of crisis for the institution of social partnership and the Irish state gave CSOs a chance to secure a collective position on a difficult set of circumstances over a rapidly unfolding crisis. While it is likely that these organisations, well used to managing challenging circumstances may have gained such control without the research process, it is extremely unlikely that the same organisations would have documented it. The research report accompanying this project provides that documentation. Moreover, given that the pillar itself was constructed by what was by 2009 an ailing political regime, the collective stance of community organisations on the lifecycle and the position of vulnerable groups in a deep recession 
would most certainly not have been negotiated, captured and communicated to the new government of 2011. Communicating the contribution of CSOs to the new government was an action-based outcome of the research report, which was launched by a minister of the new regime. The research team also offered to continue this dialogue into the future. Most interestingly, the Principal Investigator has since been asked to author position papers on particular elements of government policy by community sector organisations who are not members of the CVP. On reflection, our study shows that careful participant recruitment considerations, researcher-participant objectivity and trust and empathy-building can help build a genuinely interactive research process which generates accurate, usable and meaningful policy-orientated research.

\section{Conclusion: lessons learned for future Action Research studies}

This article demonstrated the use of Participatory Action Research to construct an allinclusive account of the lived experiences of Civil Society Organisations in the Community and Voluntary Pillar of social partnership in Ireland. In doing this, the paper has added to the strand of action research which involves government, unions and other key players in evaluating social and industrial policy as it is being developed. A key contribution of the paper is as a reflective consideration of PAR design, execution and participant integration in the research process. Throughout the paper we frequently identify useful aspects of PAR in our analysis of the case. In particular, we highlight 
how PAR played a crucial role in initiating and maintaining high levels of trust and empathy between participants and researchers. We are open and transparent about both positive and negative aspects of the PAR journey which are used to enrich a conversation about formative evaluation, an important aspect of the action research agenda. The article began with a contextual background to the research project and Ireland's social partnership model identifying the specific role for CSOs within its CVP. The importance of an action-research agenda was reviewed; in particular the role of the PAR as a research methodology. This provided a basis for the analysis which followed, developing a reflective contextualisation of PAR in terms of engaging participant organisations, building trust and empathy, and considering the utility of the research techniques and analytical tools used. This detailed account of the challenges and rewards of engaging in this formative evaluation can be of use to others employing this approach to understand complex, collective and contentious aspects of policy-making.

\section{References}

Ataöv, A., Brøgger, B. and Hildrum, J. S. (2010). An action research approach to the inclusion of immigrants in work life and local community life Preparation of a participatory realm Action Research, 8 (3), 237-265.

Aziz, A., Shams, M \& Khan, K.S. (2011). Participatory action research as the approach for women's empowerment. Action Research, 9 (3), 303-323. 
Brydon-Miller, M. Kral, M. Maguire, P. Noffke, S. and Sabhlok, A. (2011) Jazz and the Banyan Tree: Roots and riffs on Participatory Action Research. In Denzin, N. K. \& Lincoln, Y. S. (eds). Handbook of Qualitative Research (387400). Second Edition, Thousand Oaks: SAGE.

Chambers, R. (1997). Whose Reality Counts? Putting the First Last. Rugby: Practical Action.

Daly, S., (2007). Mapping Civil Society in the Republic of Ireland. Community Development Journal, 43(2), 157-176.

Department of Taoiseach. (2007). Programme for Government 2007-2012. http://www.taoiseach.gov.ie

Department of Taoiseach .(2006).Towards 2016: Ten Year Framework Social Partnership Agreement 2006-2015, http://www.taoiseach.gov.ie

Denzin, N. K., (2011).The Politics of Evidence. In Denzin, N. K. \& Lincoln, Y. S. (Eds.), The SAGE Handbook of Qualitative Research (pp. 645-658) Second Edition. Thousand Oaks: SAGE.

Dundon, T. \& Ryan, P. (2010). Interviewing reluctant respondents: strikes, henchmen and Gaelic games. Organisational Research Methods 13, 562-581.

Dundon, T. \& Gollan, P. (2007). Re-conceptualizing voice in the non-union workplace, International Journal of Human Resource Management ,18 (July), 1182-1999.

Dundon, T., Curran, D., Maloney, M. \& Ryan, P. (2006). Conceptualising the dynamics of employee voice: evidence from the Republic of Ireland, Industrial Relations Journal, 37 (5), 492-512.

Erikson, F. (2011). A History of Qualitative Inquiry in Social and Educational Research. In Denzin, N. K. \& Lincoln, Y. S. (eds). Handbook of Qualitative Research (pp. 43-60). Second Edition, Thousand Oaks:SAGE.

Fyfe, N.R. (2005). Making Space for "Neo-communitarianism?" The Third Sector, State and Civil Society in the UK. Antipode, 37(3), 536-557.

Gaynor, N. (2009) Deepening democracy within Ireland's Social Partnership. Irish Political Studies, 24 (3), 303-319. 
Gomez, M. V. and Kuronen, M. (2011) Comparing local practices: recollections from two qualitative cross-national research projects. Qualitative Research, 11 (6), 683697.

Gouin, RR, Cocq, K. \& McGavin, S. (2011). Feminist participatory research in a social justice organisation, Action Research, 9 (3), 261-281.

Greenwood, D. J. \& Levin, M. (1998). Introduction to Action Research: social research for social change. Thousand Oaks: SAGE.

Grootings, P., Gustavsen, B., \& Hethy, L. (1991). New Forms of Work Organisation in Europe. New Brunswick: Transaction Publishers.

Heshusius, L. (1994). Freeing Ourselves from Objectivity: managing subjectivity or turning toward a participatory mode of consciousness? Educational Researcher, 23 (3), 15-22.

Kemmis, S. \& McTaggart, R. (2000). Participatory Action Research. In Denzin, N. K. \& Lincoln, Y. S. (eds). Handbook of Qualitative Research Second Edition, Thousand Oaks: SAGE.

Larragy, J. (2006). Origins and Significance of the Community -Voluntary Pillar's Entry to Social Partnership, Economic and Social Review, 37 (3), 1-23.

Lincoln, Y. S. \& Guba, E. G. (2000). Paradigmatic Controversies, Contradictions, and Emerging Confluences. In Denzin, N. K. \& Lincoln, Y. S. (eds). Handbook of Qualitative Research Second Edition, Thousand Oaks: SAGE.

McDonough, T. \& Dundon, T. (2010). Thatcherism Delayed? The Irish crisis and the paradox of social partnership, Industrial Relations Journal, 41 (6), 544-562.

Meade, R. \& O'Donovan, O. (2002). Editorial Introduction: Corporatism and the Ongoing Debate about the Relationship between the State and Community Development.Community Development Journal, 37(1), 1-9.

Meade, R. (2005) “We Hate it Here, Please Let Us Stay!” Irish Social Partnership and the Community/Voluntary Sector's Conflicted Experiences of Recognition. Critical Social Policy, 25(3), 349-373.

Murphy, M. (2002). Social Partnership - Is it the "Only Game in Town”?Community Development Journal, 37(1), 80-90. 
Murphy, A. (2000). The Celtic Tiger - An Analysis of Ireland's Economic Growth Performance. RSC No. 2000/16, EU Working Papers at http://www.eui.eu/RSCAS/WP-Texts/00_16.pdf

National Economic and Social Council. (2005) . The Developmental Welfare State, Report No. 113. Dublin: National Economic and Social Development Office.

Naschold, F., Cole, R., Gustavsen, B..\& van Beium, H. (1993). Constructing the New Industrial Democracy. Maastricht: Arbetslivscentrum.

Palshaugen, O. (1997). Organisation Development through development organisation. In Gustavsen, B., Colbjornsen \& Palshaugen, O. (Eds.) Development Coalitions in Working Life: the 'Enterprise Development 2000' Programme in Norway. Amsterdam: John Benjamins.

Roche, W. K. (2010). The Breakdown of Social Partnership, Industrial Relations Conference 2010/Industrial Relations News, Issue 10 (10 ${ }^{\text {th }}$ March).

Teague, P. \& Donaghey, J. (2009). Social Partnership and Democratic Legitimacy in Ireland. New Political Economy. 14 (1), 51-71.

Toulmin, S. \& Gustavsen, B. (1996). Beyond Theory: changing organisations through participation. Philadelphia: John Benjamins.

United Nations (2008). People Matter: Civic Engagement in Public Governance.World Public Sector Report 2008. NY: United Nations.

Wilkinson, A., Dundon, T., Marchington, M. \& Ackers, P. (2004). The changing patterns of employee voice: case studies from the UK and Republic of Ireland., Journal of Industrial Relations, 46 (3), 298-323.

Acknowledgements: 


\footnotetext{
${ }^{\mathrm{i}}$ The seven national partnership agreements are: 1987, Programme for National Recovery (PNR); 1991, Programme for Economic and Social Progress (PESP); 1994, Programme for Competitiveness and Work (PCW); 1997, Partnership 2000; 1999, Programme for Prosperity and Fairness (PP\&F); 2001, Sustaining Progress; 2006-2016, Towards 2016. In 2010 a public sector only worker agreement was negotiated, the Public Service Agreement 2010-2014 (otherwise known as the 'Croke Park' agreement).

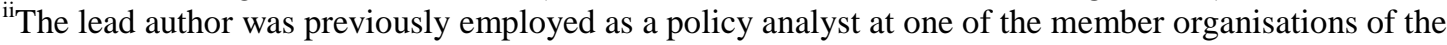
CVP. The second author was a former trade union officer, now an academic at the same university as the lead author, and this added a specialism around social partnership as a bargaining institution. The third author is an employed researcher at the University's research centre, who has long experience of undertaking research commissioned by community organisations.

iii No incentive was offered to the participants. Those who did take part were sent a $€ 100$ token in appreciation of their participation following publication of the final report. They were not made aware of this at any stage in the research process.
} 